\title{
Effect of Different Levels of Dietary Carbohydrate on Growth and Metabolic Enzyme Activity in Clarias batrachus (Linnaeus, 1758)
}

\author{
Aprajita*, Kamal Kant Jain, Narrottam Prasad Sahu, Md Aklakur and Amit Ranjan
}

Fish Nutrition Biochemistry and Physiology Division, ICAR- Central Institute of Fisheries

Education, PanchMarg, Versova, Andheri (W), Mumbai- 400001, India

*Corresponding author

\section{A B S T R A C T}

\begin{tabular}{|l|}
\hline Ke y w o r d s \\
$\begin{array}{l}\text { Dietary carbohydrate, } \\
\text { Clarias batrachus, } \\
\text { Growth, Metabolic } \\
\text { enzymes. }\end{array}$ \\
\hline Article Info \\
\hline $\begin{array}{l}\text { Accepted: } \\
10 \text { September } 2017 \\
\text { Available Online: } \\
10 \text { November } 2017\end{array}$ \\
\hline
\end{tabular}

A 60-days feeding trial was conducted to assess the growth and metabolic enzyme activity in Clarias batrachus fingerlings fed with graded levels of digestible carbohydrate (DC). Ninety fingerlings (90) of Clarias batrachus (Av. Wt. 5.5g) were stocked in three distinct experimental groups in triplicates following completely randomized design. Three experimental diets viz. $20 \%$ DC (T1), 30\% DC (T2) and 40\% DC (T3) were fed to Clarias batrachus fingerlings. The lowest weight gain was observed in the group fed with $20 \%$ DC (T1). Specific growth rate (SGR) and protein efficiency ratio (PER) were significantly $(\mathrm{p}<0.05)$ higher in T2 and T3 groups than the T1 group. Activities of intestinal amylase and liver Glucose - 6 - phosphate dehydrogenase (G-6-PDH) enzymes were significantly higher $(\mathrm{p}<0.05)$ in T3 group. Both T2 and T3 groups showed higher aspartate amino transferase (AST) and alanine amino transferase (ALT) activities in both liver and muscle tissues. No significant change was observed in the hexokinase activity in the liver and muscle tissues $(p>0.05)$. Hence, from the findings of the present study it can be concluded that the dietary inclusion of $40 \%$ DC can be used effectively in aqua feed formulation without compromising the growth of $C$. batrachus.

\section{Introduction}

Fish feed represents around 40-50\% of total aquaculture production costs. Carnivorous and omnivorous fishes have high protein requirements than herbivorous fishes in their diet, which results in high feed costs (Buhler and Halver, 1961). Also, fish preferentially use protein energy for metabolism. Thus, protein in diet mainly goes for metabolism rather than growth. But it has been already found in many studies that increasing digestible carbohydrate in the diet can be used to spare protein in diet (Hemre et al., 1989; Shiau et al., 1993; Azaza et al., 2013). Carbohydrates are easily available and inexpensive source in formulated feeds, which are efficiently utilised in several fish species (Gao et al., 2010). Carbohydrate utilization of fish varies between fish species and carbohydrate sources (Wilson, 1994; Moon, 2001; Krogdahl et al., 2005). Di- and monosaccharide are more digestible to catfishes with maximum protein retention and energy retention rate (Erfanullah and Jafri, 1999). Also, physical treatments like extrusion, cooking etc, gelatinise carbohydrate thus easing the process of fish digestion (Tester and Morrison, 1990). Prepared feeds for carnivorous fish usually 
contain less than 20 percent soluble carbohydrate, while feeds for omnivorous species usually contain 25 to 45 percent (Buhler and Halver, 1961). The ability of carnivorous fish species to hydrolyze or digest complex carbohydrates is limited due to the weak amylotic activity in their digestive tract (Spannhof and Plantikow, 1983). However, reduced growth rates have been observed in some species when fed carbohydrate-free diets (Degani et al., 1986). Alternatively, feeding excessive dietary carbohydrate to fish has been shown to adversely affect an array of morphometric and physiological parameters used to measure growth and nutrient utilization or physiological function (Hilton and coworkers, 1983; Dixon and Hilton, 1985; Hemre et al., 1989). This implies higher level of carbohydrate than required is not going to spare protein contributing to growth. Thus, it is evident to optimize the level of carbohydrate for each species according to their utilisation capacities. Therefore, the present study was conducted with an objective to assess the different levels of dietary carbohydrate on growth and metabolic enzyme activity in Clarias batrachus fingerlings (Linnaeus, 1758).

\section{Materials and Methods}

\section{Experimental animals and experimental set up}

Asian catfish (Magur), C. batrahus (Linnaeus, 1758) were procured from Powarkheda centre of Central Institute of Fisheries Education (CIFE), Madhya Pradesh, India. The experiment was conducted for a period of 60 days in the wet laboratory of Central Institute of Fisheries Education. The setup consisted of 9 plastic rectangular tubs $(57 \times 36 \times 47 \mathrm{~cm}$, $75 \mathrm{~L}$ capacity) covered with perforated lids. Ten fishes with initial weight ranging from 5.2-5.8g (Av. wt. 5.5g) were stocked in each plastic tub with $50 \mathrm{~L}$ chlorine free bore well water. The total volume of water was maintained throughout the experimental period. Round the clock aeration was provided. To provide shelter to fingerlings plastic hide outs was placed at the bottom of each tub. Fishes were fed up to satiation two times a day for 60 days. Fortnightly, measurements of fish weight were taken.

\section{Experimental diets}

Three iso-nitrogenous (38.2\%) and iso-lipidic diets $(8 \%)$ with different levels of gelatinised starch and dextrin as carbohydrate sources were prepared. The level of carbohydrate in three diets were $\mathrm{T} 1$ (20\% CHO), T2 (30\% $\mathrm{CHO}$ ) and $\mathrm{T} 3(40 \% \mathrm{CHO})$. Composition of diet is given in Table 1 .

\section{Diet preparation}

Pre- weighed required ingredients as per formulation were mixed with gelatinised starch to form dough. Then dough was then cooked for half an hour in a pressure cooker. When the steamed dough was completely cooled, the calculated concentration of the oils, vitamin and mineral mixture were incorporated in it and mixed well and pressed through a semi-automatic pelletizer to get uniform sized pellets, which were air dried and packed in airtight polythene bags were labelled according to the treatments.

\section{Sampling and analysis of samples}

\section{Proximate analysis}

Proximate composition of the fish and diets were analysed following standard methods of AOAC (1995). Moisture was determined by drying the sample at $105^{\circ} \mathrm{C}$ to a constant weight. The nitrogen content of the sample was analyzed using Kjeltec system (2200 Kjeltec Auto distillation, Foss Tecator, 
Sweden) and crude protein was calculated by multiplying nitrogen percentage by 6.25 . Ether extract (EE) was determined using Soxtec system (1045 Soxtec Extraction Unit, Foss Tecator, Sweden) using diethyl ether (boiling point, $60-80^{\circ} \mathrm{C}$ ) as a solvent and the ash content was estimated by incinerating sample in a muffle furnace at $600^{\circ} \mathrm{C}$ for $6 \mathrm{~h}$. The fibre was estimated in FIBRO tech extraction apparatus by giving acid followed by alkali digestion. Total carbohydrate was calculated by differences as carbohydrate $\%=$ $100-(\mathrm{CP} \%+\mathrm{EE} \%+\mathrm{Ash} \%)$. The digestible energy (DE) value of experimental diets and tissue was calculated as described by Halver (1976).

\section{Enzyme assays}

At the end of the experiment (T1, T2 and T3), 3 fishes were collected from each tank and anesthetized with clove oil $\left(50 \mu \mathrm{L}^{-1}\right)$. Fishes were then dissected and the tissues viz., liver, intestine and muscle, were immediately removed. A 5\% tissue homogenate was prepared in chilled $0.25 \mathrm{M}$ sucrose solution by Teflon coated mechanical homogeniser (MICCRA D-9, Digitronic, Germany). The whole procedure was followed in ice cold condition. Homogenized samples were centrifuged at $5000 \mathrm{rpm}$ for $10 \mathrm{~min}$ at $4^{\circ} \mathrm{C}$. The supernatant was collected in $5 \mathrm{ml}$ plastic vials and stored in a deep freezer $\left(-20^{\circ} \mathrm{C}\right)$ for enzyme assay. Total protein content was analyzed from the supernatant (Lowry et al., 1951) for calculating enzyme activities. All the colorimetric assays were carried out using UV-VIS spectrophotometer (E-Merck, Germany).

\section{Digestive enzymes}

Amylase (E.C. 3.2.1.1) activity was measured by estimating the reducing sugars produced due to the action of $\alpha$-amylase on starch (Rick and Stegbauer, 1974). A 2\% starch solution was prepared in phosphate buffer $(\mathrm{pH} 7.0)$ The reaction mixture, consisting of starch solution, buffer and tissue homogenate, was incubated at $37{ }^{\circ} \mathrm{C}$ for $30 \mathrm{~min}$. Then dinitrosalicylic acid was added to stop the reaction and kept in boiling water for $5 \mathrm{~min}$. After cooling, the reaction mixture was diluted with distilled water and absorbance recorded at $540 \mathrm{~nm}$. Activity was determined from the maltose standard curve and expressed as mole of maltose released from starch $/ \mathrm{min} / \mathrm{mg}$ protein at $37^{\circ} \mathrm{C}$.

\section{Metabolic enzymes}

\section{Hexokinase}

Hexokinase (HK; E.C. 2.7.1.1) activity was measured by the method of Easterby and O'Brien (1973). A reaction cocktail was prepared by mixing Tris- $\mathrm{HCl}$ buffer (50 $\mathrm{mM})$, glucose $(50 \mathrm{mM})$, adenosine triphosphate $(30 \mathrm{mM})$ and $\mathrm{MgCl} 2(200 \mathrm{mM})$. The $\mathrm{pH}$ was adjusted to 7.6 at $30^{\circ} \mathrm{C}$.

The final reaction mixture consisted of reaction cocktail, $\beta$-NADP $(1 \mathrm{mM})$ and G6PDH $(500 \mathrm{U} / \mathrm{mL})$. One unit of enzyme is defined as the amount of enzyme activity that phosphorylates $1.0 \mu \mathrm{mol}$ of D-glucose/ min at $30{ }^{\circ} \mathrm{C}$.

\section{Glucose -6-Phosphate Dehydrogenase (G-6- PDH)}

The G-6-PDH activity in different tissues was assayed by the method of De Moss (1953). Total $3 \mathrm{ml}$ of the reaction mixture was comprised of $1.5 \mathrm{ml}$ of $0.1 \mathrm{M}$ Tris buffer $(\mathrm{pH}$ 7.8 ), $0.2 \mathrm{ml}$ of $2.7 \mathrm{mM}$ NADP, $0.1 \mathrm{ml}$ of tissue homogenate, $1.05 \mathrm{ml}$ of distilled water and $0.1 \mathrm{ml}$ of $0.02 \mathrm{M}$ glucose-6-phosphate (G6P). The reaction was started by adding G6P as substrate. The OD was recorded at $340 \mathrm{~nm}$ at 15 second interval against distilled water. The G6PDH activity was expressed as unit mg 
protein $^{-1} \min ^{-1}$. One unit was equal to $\Delta 0.01$ OD $\min ^{-1} \mathrm{ml}^{-1}$ at $25^{\circ} \mathrm{C}$.

\section{Alanine amino-transferase}

Alanine amino-transferase (ALT; E.C. 2.6.1.2.) was assayed with $200 \mathrm{mM} \mathrm{DL}$ alanine and $2 \mathrm{mM} \alpha$-ketoglutarate in $40 \mathrm{mM}$ phosphate buffer ( $\mathrm{pH}$ 7.4), and estimated at $540 \mathrm{~nm}$ (Wootton, 1964). Aspartate aminotransferase (AST; E.C. 2.6.1.1.) was assayed by the same procedure as for ALT except for the substrate, $200 \mathrm{mM}$ DL-aspartic acid instead of alanine (Wootton, 1964). The enzyme activity was expressed as nanomoles oxaloacetate formed $/ \mathrm{min} / \mathrm{mg}$ protein at $37^{\circ} \mathrm{C}$.

\section{Statistical analysis}

Data were analyzed using one-way analysis of variance (ANOVA) via SPSS v.22 software. Duncan's multiple range test was used for post hoc comparison of means $(\mathrm{P}<0.05)$.All data presented in the text, figures and tables are means \pm standard error and statistical significance for all statistical tests was set at $\mathrm{P}<0.05$.

\section{Results and Discussion}

\section{Physio-chemical parameters of water}

The water temperature of the different experimental groups ranged from $27.2^{\circ} \mathrm{C}$ to $27.8^{\circ} \mathrm{C}$ throughout the experimental period. The $\mathrm{pH}$ values were recorded within the range of 7.5 to 8.0. The dissolved oxygen concentration of all the experimental groups was recorded within the range of 5.6 to $7.8 \mathrm{mLL}^{-1}$. The free carbon dioxide was not detected in the cultured water. Carbonate hardness was found to be $228-245 \mathrm{mgL}^{-1}$. The total ammonia content of all the experimental groups was found to be in the range of 0.14 to $0.27 \mathrm{mgL}^{-1}$. The nitrite- $\mathrm{N}$ content was found to be in the range of 0.001 to $0.005 \mathrm{mgL}^{-1}$. The nitrate- $\mathrm{N}$ content was found to be in the range of 0.02 to $0.06 \mathrm{mgL}^{-1}$, during the experimental period. All the physio-chemical parameters of the source water used for the present study were found to be in the optimum range (Jhingran, 1991). Therefore, the variation in the finding can be attributed to the dietary factors applied.

\section{Proximate composition of diet}

Proximate composition of the experimental diets is presented in Table 2. Moisture content in the diet was observed between $7.10 \%$ and $7.33 \%$ and crude protein in the diet varied from $37.97 \%$ to $38.10 \%$. The ether extract (EE) content varied from $7.77 \%$ to $7.96 \%$, whereas the ash of the diet varied from $2.08 \%$ to $2.37 \%$.

\section{Growth Parameters}

The data pertaining to growth parameters are presented in Figures 1 to 4. Weight gain, specific growth rate and protein efficiency ratio were significantly lower $(\mathrm{p}<0.05)$ in $20 \%$ carbohydrate fed group (T1) than the other two treatments. Weight gain and specific growth rate were observed similar (p>0.05) in $30 \%$ and $40 \%$ carbohydrate fed group (T2 and T3 respectively). Similar results was seen in finding of Jantrarotai $e t$ al., (1994) who found that weight gain hybrid Clarias catfish (Clarias macrocephalus $\times C$. gariepinus) fed a diet containing $36 \%, 44 \%$, $49 \%$ carbohydrate did not differ significantly $(\mathrm{P}<0.05)$. This may be due to the fact that when dietary energy is more than required level, it may reduce diet digestibility and growth. Even, it was observed in rainbow trout fed a diet containing 30\% starch that growth and feed efficiency were improved by increasing gelatinized, starch but reached a plateau at around 40\% which supports the finding of the present study (Jeong et al., 1992). The feed conversion ratio was 
significantly higher $(\mathrm{p}<0.05)$ in the $\mathrm{T} 1$ group while it was found similar T2 and T3 groups ( $p>0.05$ ). This may be due to low level of gelatinised starch $(20 \%)$ in T1 diet compared to T2 $(30 \%)$ and T3 (40\%). It is supported by findings of Banos et al., (1998), it was found that even if there is a supplementation of the extruded carbohydrate source of higher inclusion level (even of 37\%) in diet, rainbow trout did not show slower growth than fishes fed with $20 \%$ raw starch. This result was found in correlation to the findings of several authors (Mohapatra et al., 2003; Yengkokpam et al., 2007) which demonstrated that gelatinization improves the carbohydrate digestibility and thus can incorporate more carbohydrate in the diet of the fish. Also, Erfanullah and Jafri (1998) observed highest weight gain, FCR, SGR and protein retention in C. batrachus fingerlings fed with diet $27 \%$ white dextrin and 8\% lipid diet. There was no significant $(\mathrm{p}>0.05)$ increase in weight in T3 (40\% CHO) compared to $\mathrm{T} 2(30 \% \mathrm{CHO})$ with the increase in the percent of gelatinised carbohydrate.

\section{Digestive and metabolic enzymes}

\section{Amylase}

The amylase activity is shown in Table 3. The amylase activity was found significantly lower $(\mathrm{p}>0.05)$ in $\mathrm{T} 1$ whereas, its activity was similar inT2 and T3 groups $(\mathrm{p}>0.05)$. In the present study, there was significant $(p<0.05)$ increase in amylase activity from $\mathrm{T} 1$ to $\mathrm{T} 3 \mathrm{fed}$ groups (Table 3). This is in accordance with the findings of Mukhopadhyay (1976), who also reported the increase in amylase activity in $C$. batrachus fed with high carbohydrate.

Table.1 Composition of the experimental diets

\begin{tabular}{lccc}
\hline Ingredients & $\mathrm{T} 1(20 \%)$ & $\mathrm{T} 2(30 \%)$ & $\mathrm{T} 3(40 \%)$ \\
\hline Casein & 35 & 35 & 35 \\
Gelatin & 7 & 7 & 7 \\
Dextrin & 10 & 15 & 20 \\
Pre-gelatinised starch & 10 & 15 & 20 \\
Cellulose & 25.6 & 15.6 & 5.6 \\
Cod liver oil & 4 & 4 & 4 \\
Sunflower oil & 4 & 4 & 4 \\
CMC & 1 & 1 & 1 \\
Vitamin and mineral mix * & 2 & 2 & 2 \\
Choline chloride & 0.88 & 0.88 & 0.88 \\
Betaine hydrochloride & 0.5 & 0.5 & 0.5 \\
BHT & 0.02 & 0.02 & 0.02 \\
\hline
\end{tabular}

*Composition of vitamin mineral mix (PRE-EMIX PLUS) (quantity/kg) -Vitamin A, 55,00,000 IU; Vitamin D3, 11,00,000 IU; Vitamin B2, 2,000 mg; Vitamin E, $750 \mathrm{mg}$; Vitamin K, 1,000 mg; Vitamin B6, 1,000 mg; Vitamin B12, $6 \mathrm{mcg}$; Calcium Pantothenate, 2,500 mg; Nicotinamide, $10 \mathrm{~g}$; Choline Chloride, $150 \mathrm{~g}$; Mn, 27,000 mg; I, $1,000 \mathrm{mg} ; \mathrm{Fe}, 7,500 \mathrm{mg}$; Zn, 5,000 mg; Cu, 2,000 mg; Co, $450 \mathrm{~L}-$ lysine, $10 \mathrm{~g}$; DL- Methionine, $10 \mathrm{~g}$; Selenium, $125 \mathrm{mg}$.

Abbreviations: CMC- Carboxymethyl cellulose; BHT- Butylatedhydroxy toluene 
Table.2 Proximate composition of the different experimental diets (\% DM basis)

\begin{tabular}{lccc}
\hline Treatments & $\mathrm{T} 1$ & $\mathrm{~T} 2$ & $\mathrm{~T} 3$ \\
\hline Dry matter & $92.99 \pm 0.15$ & $92.66 \pm 0.16$ & $92.76 \pm 0.23$ \\
Crude protein & $38.10 \pm 0.10$ & $38.36 \pm 0.22$ & $37.97 \pm 0.12$ \\
Ether extract & $7.95 \pm 0.05$ & $7.77 \pm 0.10$ & $7.96 \pm 0.09$ \\
Total ash & $2.20 \pm 0.06$ & $2.37 \pm 0.16$ & $2.08 \pm 0.02$ \\
Crude fibre & $25.11 \pm 0.31$ & $15.06 \pm 0.08$ & $5.53 \pm 0.05$ \\
Nitrogen free extract (NFE) & $19.54 \pm 0.29$ & $29.11 \pm 0.05$ & $39.23 \pm 0.48$ \\
DE (Kcal/100g) & $302.14 \pm 0.79$ & $339.82 \pm 0.92$ & $380.43 \pm 0.87$ \\
\hline
\end{tabular}

Data expressed as mean $\pm \mathrm{SE}, \mathrm{n}=3$.

Table.3 Activity of metabolic enzymes in sampled fishes fed with different diets

\begin{tabular}{lccc}
\hline Treatments & $\mathrm{T} 1$ & $\mathrm{~T} 2$ & $\mathrm{~T}$ \\
\hline Amylase & $1.26^{\mathrm{a}} \pm 0.20$ & $2.25^{\mathrm{b}} \pm 0.13$ & $2.41^{\mathrm{b}} \pm 0.32$ \\
Hexokinase (Liver) & $0.50 \pm 0.08$ & $0.57 \pm 0.05$ & $0.64 \pm 0.05$ \\
Hexokinase (Muscle) & $2.31 \pm 0.66$ & $2.74 \pm 0.24$ & $2.5 \pm 0.35$ \\
G-6PDH (Liver) & $0.97^{\mathrm{a}^{\mathrm{a}}} \pm 0.12$ & $1.12^{\mathrm{a}} \pm 0.03$ & $1.63^{\mathrm{b}} \pm 0.05$ \\
G-6PDH (Muscle) & $1.32^{\mathrm{a}} \pm 0.06$ & $1.64^{\mathrm{a}} \pm 0.05$ & $2.13^{\mathrm{b}} \pm 0.11$ \\
AST (Liver) & $14.59^{\mathrm{a}} \pm 0.50$ & $17.41^{\mathrm{b}} \pm 0.22$ & $18.52^{\mathrm{b}} \pm 0.19$ \\
AST (Muscle) & $20.06^{\mathrm{a}} \pm 0.25$ & $24.55^{\mathrm{b}} \pm 0.18$ & $25.32^{\mathrm{c}} \pm 0.19$ \\
ALT(Liver) & $18.74^{\mathrm{a}} \pm 0.24$ & $23.67^{\mathrm{b}} \pm 0.42$ & $26.09^{\mathrm{b}} \pm 0.27$ \\
ALT(Muscle) & $24.17^{\mathrm{a}} \pm 0.25$ & $29.90^{\mathrm{c}} \pm 0.33$ & $27.17^{\mathrm{b}} \pm 0.24$ \\
\hline
\end{tabular}

Data expressed as mean $\pm \mathrm{SE}, \mathrm{n}=3$; Mean values in the same column with different superscript differ significantly $(\mathrm{P}<0.05)$. Units: Amylase ( $\mu \mathrm{m}$ of maltose released $/ \mathrm{min} / \mathrm{mg}$ protein), AST ( $\mathrm{nM}$ oxaloacetate formed $/ \mathrm{min} / \mathrm{mg}$ protein), ALT (nM pyruvate formed/min/mg protein), Hexokinase (Milli units/min/mg protein), G-6-PDH ( $\mu \mathrm{g}$ of phosphorus released/min/mg protein).

Fig.1 Percentage weight gain of the Clarias batrachus fingerlings fed with different experimental diets. Bar bears the same superscript do not differ significantly $(p>0.05)$

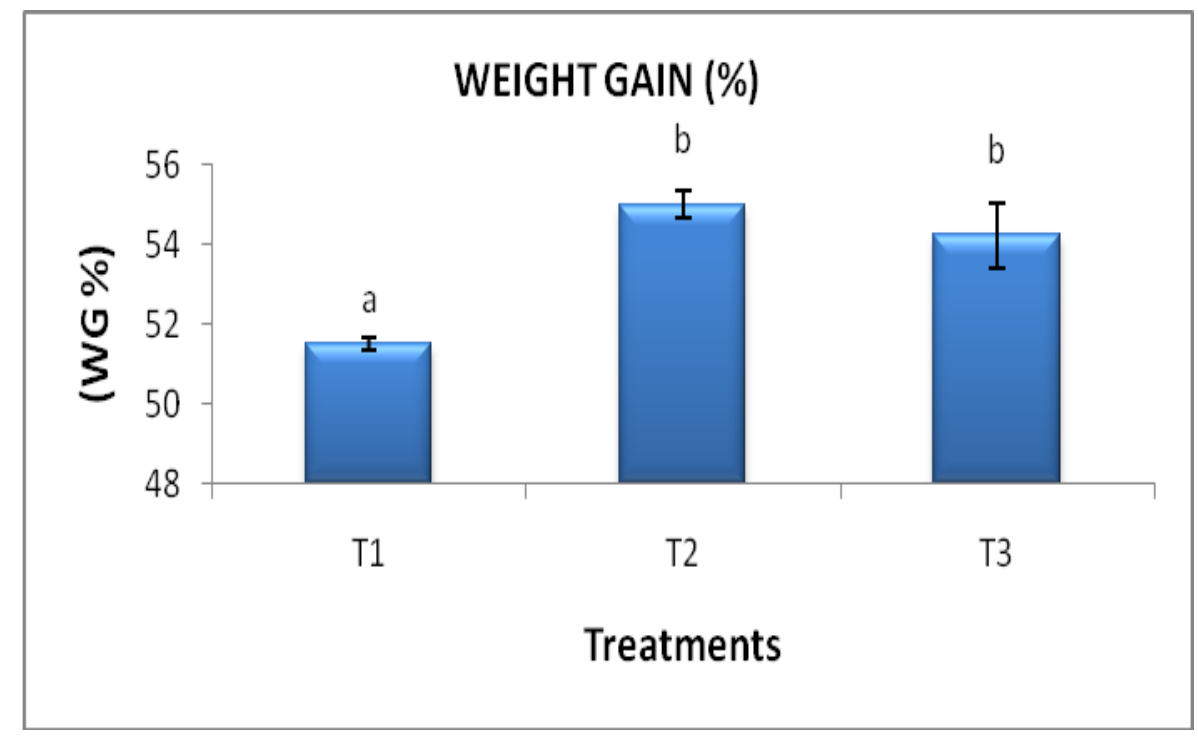


Fig.2 Specific growth rate (SGR) of Clarias batrachus fingerling fed with different experimental diets. Bar bears the same superscript do not differ significantly $(\mathrm{p}>0.05)$

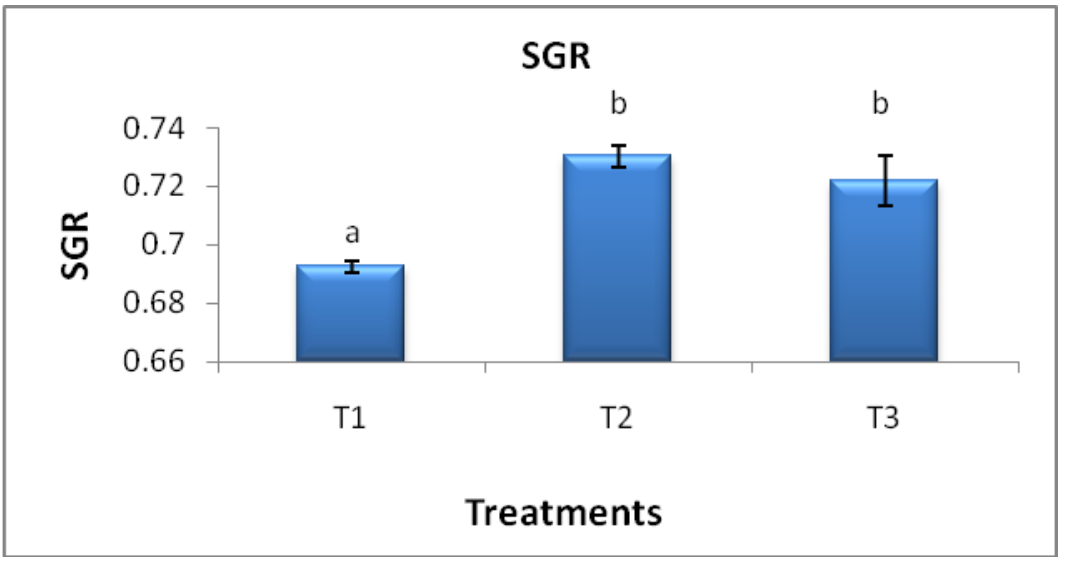

Fig.3 Feed conversion ratio (FCR) of Clarias batrachus fingerling fed with different experimental diets. Bar bears the same superscript do not differ significantly $(\mathrm{p}>0.05)$

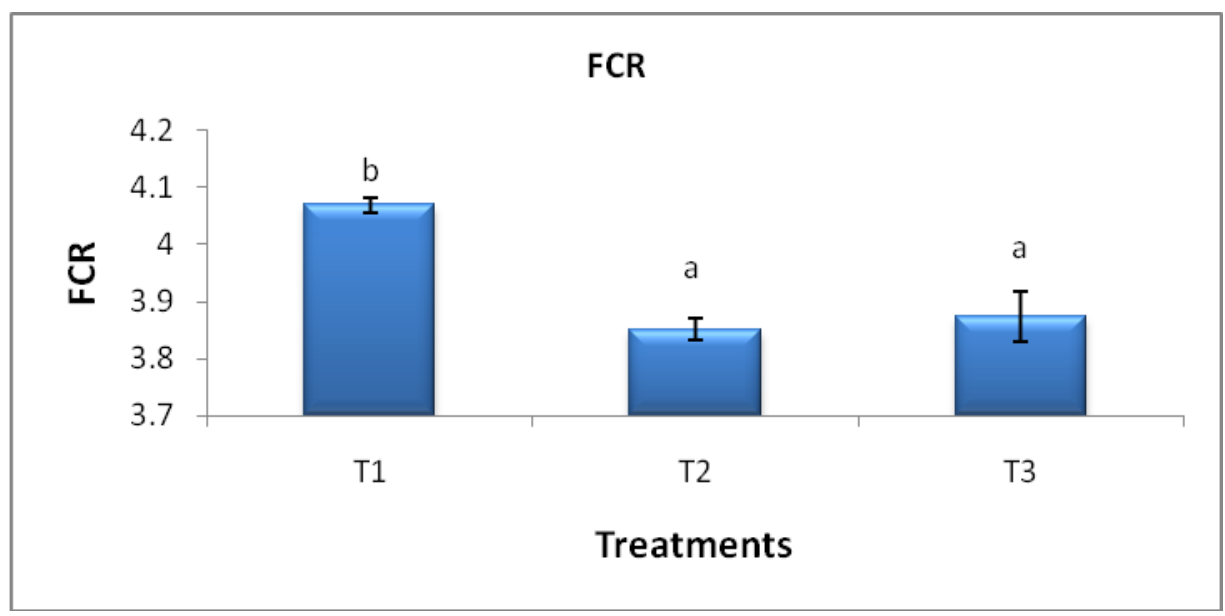

Fig.4 Protein efficiency ratio (PER) of Clarias batrachus fingerling fed with different experimental diets. Bar bears the same superscript do not differ significantly $(p>0.05)$

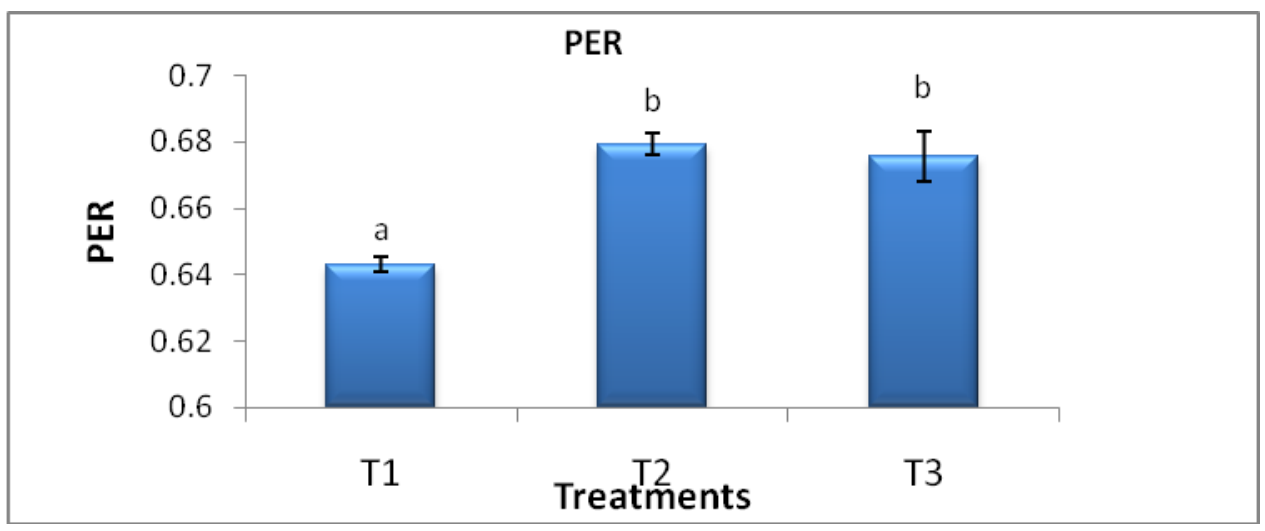


Aspartate aminotransferase (AST) and alanine aminotransferase (ALT)

The ALT and AST activity of muscle and liver tissue of different treatments were recorded in the Table 3. The AST and ALT activity in the muscle and liver were significantly lower $(\mathrm{p}<0.05)$ in the $\mathrm{T} 1$ group compared to other treatment groups. The activity of these enzymes showed no significant difference $(p>0.05)$ between $\mathrm{T} 2$ and T3 groups in liver tissue. In muscle, AST activity was significantly higher in $\mathrm{T} 3$ than $\mathrm{T} 1$ and T2 groups. However, ALT activity was significantly $(\mathrm{p}<0.05)$ higher in the $\mathrm{T} 2$ group than T3 treatment group. Transaminases are the enzymes that redistribute amino nitrogen among the amino acids, forming new amino acid with the amino group from the preexisting ones. Both the aspartate and alanine aminotransferase acts as a link between carbohydrate and protein metabolism by catalyzing the inter conversion of compounds like $\alpha$ - ketoglutarate and alanine to pyruvic acid and glutamic acid (Knox and Greengard, 1965). The pyruvate and oxaloacetate thus formed are responsible for the synthesis of non-essential amino acids like alanine, asparagine, glutamine etc. which in turn help in protein synthesis and hence the growth of the animal. In the present study, the AST and ALT activity was studied in liver and muscle tissue. In liver higher AST activity $(\mathrm{p}<0.05)$ was found in $\mathrm{T} 2$ and $\mathrm{T} 3$ than $\mathrm{T} 1$, whereas in muscle highest activity $(p<0.05)$ was seen in T3 group. ALT activity in muscle was highest in T2 (Table 3). This shows that a higher activity of these enzymes is responsible for growth by increasing the supply of nonessential amino acids for protein synthesis (Sanchez-Muros et al., 1998).

\section{Hexokinase}

Hexokinase activity (Table 3 ) in both liver and muscle tissues did not vary significantly (p>0.05) among different treatment groups. Hexokinase is a glucose phosphorylating enzyme which converts glucose to glucose-6phosphate. In the present study, there was not any significance $(p>0.05)$ difference in hexokinase activity among the treatment groups (Table 3). This shows that glycolytic pathway is not affected by dietary carbohydrate up to the $40 \%$ inclusion. A similar result was reported by Legate et al., (2001), where he found no observable change in the activity of enzyme in muscle with the difference in diet composition.

\section{Glucose-6-phosphate dehydrogenase (G-6- PDH)}

The G-6-PDH enzyme activity of the different experimental groups is presented in the Table 3. The G-6-PDH enzyme activity was significantly higher $(\mathrm{p}<0.05)$ in the T3 treatment group for liver and muscle tissues compared to other two treatment groups. There was no significant difference $(\mathrm{p}>0.05)$ observed between the other two groups (T1 and T2). Glucose-6-phosphate dehydrogenase is an enzyme of the pentose phosphate pathway which play role in fatty acid biosynthesis. In this experiment, the enzyme activity was significantly higher $(\mathrm{p}<0.05)$ in T3 fed groups as compared to T1 and T2 (Table 3). It is in accordance with the reports of Likimani et al., (1982), who observed that the G-6-PDH activities were increased with higher levels of gelatinized carbohydrate in diet of channel catfish. Therefore, the present study, indicates the preferred anabolic use of carbohydrate by fish up to a level of $40 \%$ inclusion.

Carbohydrate utilization is the key concern for economic feeding in aquaculture. The growth and related digestive and metabolic enzymes, assessed in $C$. batrachus fingerlings, fed with different dietary carbohydrate levels $\left(20 \%-\mathrm{T}_{1}, 30 \%-\mathrm{T}_{2}\right.$ and 
$40 \%-\mathrm{T}_{3}$ ) for 60 days indicated the better utilization ability of carbohydrate by the species at higher inclusion level of dietary carbohydrate. Therefore, it can be concluded that dietary inclusion of $40 \%$ carbohydrate is economic in aquafeed formulation of $C$. batrachus for better growth without any adverse impact on metabolism.

\section{Conflict of interest}

The authors declare that there are no conflicts of interest.

\section{Acknowledgments}

The authors are grateful to the Director, Central Institute of Fisheries Education (CIFE), Mumbai, India for providing facilities for carrying out the work.

\section{References}

AOAC. (1995) Official Methods of Analysis of the Association of Official Analytical Chemists, 16th edn, Vol. 1, (ed. by P.A.Cunnif), AOAC International, Arlington, USA.

Azaza, M.S., Khiari, N., Dhraief, M.N., Aloui, N., Kraiem, M.M. and Elfeki, A. (2013) Growth performance, oxidative stress indices and hepatic carbohydrate metabolic enzymes activities of juvenile Nile tilapia (Oreochromis niloticus), in response to dietary starch to protein ratios. Aquaculture Research,1-14.

Banos, N., Baro, J., Castejon, C., Navarro, I. and Gutierrez, J., 1998. Influence of high carbohydrate enriched diets on plasma insulin levels and insulin and IGF-I receptors in trout. Regulatory Peptides, 77: 55-62.

Buhler, D.R. and Halver, J.E. (1961) Nutrition of salmonoid fishes. 9. Carbohydrate requirements of Chinook salmon. Journal of Nutrition, 74, 307-
318.

Degani, G., Viola, S. and Levanon, D., 1986. Effects of dietary carbohydrate source on growth and body composition of the European eel. Aquaculture, 52: 97-104.

Demoss, R.D., Gunsalus, I.C., Bard, R.C. (1953) A Glucose-6-Phosphate Dehydrogenase from Leuconostocmesenteroides. Journal of Bacteriology, 66, 10-16.

Dixon, D.G. and Hilton, J.W., 1985. Effects of available dietary carbohydrate and water temperature on the chronic toxicity of waterborne copper to rainbow trout. Canadian Journal of Fish and Aquatic Science, 42:10071013.

Easterby, J.S. and O'Brien, M.J. (1973) Enzymatic assay of hexokinase. European Journal of Biochemistry, 38, 201-211.

Gao, W., Liu, Y.J., Tian, L.X., Mai, K.S., Liang, G.Y., Yang, H.J., Huai, M.Y. and Luo, W.J., 2010. Effect of dietary carbohydrate-to-lipid ratios on growth performance, body composition, nutrient utilization and hepatic enzymes activities of herbivorous grass carp (Ctenopharyngodon idella). Aquaculture Nutrition, 16(3): 327-333.

Halver J.E. (1976). The nutritional requirements of cultivater warm water and cold water fish species. Paper No. 31, FAO Technical Conference on Aquaculture, Kyoto, 26 May to 2.June, 9.

Hemre, G.I., Lie, O., Lied, E. and Lambertsen, G. (1989) Starch as an energy source in feed for cod (Gadus morhua), Digestibility and retention. Aquaculture, 80, 261-270.

Hilton, J. W. and Slinger, S. J., 1983. Effect of wheat bran replacement of wheat middling in extrusion processed (floating) diets on the growth of juvenile rainbow trout (Salmo 
gairdneri). Aquaculture, 35:201-210.

Jafri, A. K. (1999). Growth, feed conversion, body composition and nutrient retention efficiencies in fingerling catfish, Heteropneustes fossilis (Bloch), fed different sources of dietary carbohydrate. Aquaculture Research, 30(1), 43-49.

Jafri, A.K. (1998) Effect of dietary carbohydrate-to-lipid ratio on growth and body composition of walking catfish (Clarias batrachus). Aquaculture, 161(1), 159-168.

Jantrarotai W., Sitasit P. and Rajchapakdee S. (1994). The optimum carbohydrate to lipid ratio in hybrid Clarias catfish (Clariasmacrocephalus $\times \quad C$. gariepinus) diets containing raw broken rice. Aquaculture, 127, 61-68.

Jeong, K.S., Takeuchi, T., Okamoto, N. and Watanabe, T. (1992) The effect of dietary gelatinized ratios at different dietary energy levels on growth and characteristics of blood in rainbow trout fingerlings. Bulletin of the Japanese Society of Scientific Fisheries (Japan).

Jhingran, V. G., 1991. Fish culture in fresh water pond. In: Jhingran, V.G. Fish and Fisheries of India, III edn. Hindustan Publishing Corporation, New Delhi: 276.

Knox, W.E. and Greengard, O. (1965). The regulation of some enzymes of nitrogen metabolism-an introduction to enzyme physiology. Advances in enzyme regulation, 3, 247-313.

Krogdahl, A., Hemre, G.I. and Mommsen, T.P., 2005. Carbohydrates in fish nutrition: digestion and absorption in post larval stages. Aquaculture Nutrition, 11: 103-122.

Legate, N.J., Bonen, A. and Moon, T.W. (2001) Glucose tolerance and peripheral glucose utilization in the rainbow trout (Oncorhynchus mykiss), the American eel, (Anguilla rostrata) and the black bullhead catfish (Ameiurusmelas). General Comparative of Endocrinology, 122, 48-59.

Likimani, T.A. and Wilson, R.P. (1982) Effects of diet on lipogenic enzyme activities in channel catfish hepatic and adipose tissue. The Journal of nutrition, 112(1), 112-117.

Lowry, O.H., Ronebrough, N.J., Farr, A.L. and Randall, R.J. (1951) Protein measurement with folin phenol reagent. Journal of Biological Chemistry, 193, 265-276.

Mohapatra, M., Sahu. N.P. and Chaudhari. A. (2003) Utilization of gelatinized carbohydrate in diets in Labeo rohita fry. Aquaculture Nutrition, 9, 189-196.

Moon, T. W., 2001. Glucose intolerance in teleost fish: fact or fiction. Comparative Biochemistry and Physiology, 129: 243249.

Mukhopadhyay, P.K. (1976) Studies on the enzymatic activities related to varied pattern of diets in the air-breathing catfish C. batrahus. Hydrobiologia, 52, 235-237.

Patra, B. C., and Ray, A. K. (1988). Performance of the air-breathing fish, Clarias batrachus (Linn) at variable dietary-protein levels. Indian Journal of Animal Sciences, 58(7), 882-886.

Patra, B.C. and Ray, A.K., 1988. A preliminary study on the utilization of the aquatic weed Hydrilla verticillata Rayle as feed by the carp, Labeorohita (Hamilton): growth and certain biochemical composition of flesh. Indian Biology, 20: 44-50.

Rick, W. and Stegbauer, H.P. (1974) Amylase measurement of reducing groups. In, Bergmeyer, H.V. (Ed.), Methods of Enzymatic Analysis, Academic Press, New York, vol. 2. pp. 885-889.

Sánchez-Muros, M.J., García-Rejón, L., García-Salguero, L. and Lupiáñez, J.A. (1998) Long-term nutritional effects on 
the primary liver and kidney metabolism in rainbow trout. Adaptive response to starvation and a highprotein, carbohydrate-free diet on glutamate dehydrogenase and alanine aminotransferase kinetics. The international journal of biochemistry \& cell biology, 30(1), 55-63.

Shiau, S.Y. and Peng, C.Y., 1993. Proteinsparing effect by carbohydrates in diets for tilapia, Oreochromis niloticus $\times O$. aureus. Aquaculture, 117:327-334.

Spannhof, L. and Plantikow, H. (1983) Studies on carbohydrate digestion in rainbow trout. Aquaculture, 30, 95-108.

Tester, R.F. and Morrison, W.R. (1990) Swelling and gelatinization of cereal starches. I. Effects of amylopectin, amylose, and lipids. Cereal chemistry, 67(6), 551-557.

Wilson, R.P., 1994. Utilization of dietary carbohydrate by fish. Aquaculture, 124: 67-80.

Wootton, I.D.P. (1964). Microanalysis in Medical Biochemistry, 4th Ed. J\&A Churchill Ltd., London, pp. 101-107.

Yengkokpam, S., Sahu, N.P., Pal, A.K.; Mukherjee, S.C. and Dipesh, D. (2007) Gelatinized carbohydrates in the diets of Catlacatla fingerlings, effect of levels and sources on nutrient utilization, body composition and tissue enzyme activities. Asian Australian Journal of Animal Science, 20(1), 8.

\section{How to cite this article:}

Aprajita, Kamal Kant Jain, Narrottam Prasad Sahu, Md Aklakur and Amit Ranjan. 2017. Effect of Different Levels of Dietary Carbohydrate on Growth and Metabolic Enzyme Activity in Clarias batrachus (Linnaeus, 1758). Int.J.Curr.Microbiol.App.Sci. 6(11): 781-791. doi: https://doi.org/10.20546/ijcmas.2017.611.092 